\title{
Relationships between climate and population dynamics of white-tailed ptarmigan Lagopus leucurus in Rocky Mountain National Park, Colorado, USA
}

\author{
Guiming Wang ${ }^{1, *}$, N. Thompson Hobbs ${ }^{1}$, Kenneth M. Giesen ${ }^{2}$, Hector Galbraith ${ }^{3}$, \\ Dennis S. Ojima ${ }^{1}$, Clait E. Braun ${ }^{2}$
${ }^{1}$ Natural Resource Ecology Laboratory, Colorado State University, 1231 East Drive, Fort Collins, Colorado 80523-1499, USA
${ }^{2}$ Colorado Division of Wildlife, Wildlife Research Center, 317 West Prospect Road, Fort Collins, Colorado 80526, USA
${ }^{3}$ Galbraith Environmental Sciences, 633 Furman Way, Boulder, Colorado 80303, USA

${ }^{*}$ Present address: Natural Resource Ecology Laboratory, Colorado State University, Fort Collins, Colorado 80523-1499, USA

\begin{abstract}
The potential for anthropogenic changes in climate has raised questions about how these changes might affect wildlife populations. We fit the Ricker population model to 25 years of data on the population sizes of white-tailed ptarmigan in Rocky Mountain National Park (RMNP), Colorado, USA, using 12 different weather variables as covariates. The best approximating model for population growth rates of the ptarmigan was selected using the Akaike information criterion and Aikaike weights. Our linear regression results suggest that median hatch dates advanced significantly from 1975 to 1999 in response to increases in April and May temperatures. Our best approximating population model indicated that high winter minimum temperatures retarded the growth rate of the population. Our data also had reasonable support that high mean winter monthly minimum temperatures and high mean winter monthly maximum temperatures might lower the population growth rate of the ptarmigan. We simulated the effects of future warming on the ptarmigan population in RMNP using our best ptarmigan population model and future climate scenarios projected by the Canadian Climate Center and Hadley Centre models. Our simulation results suggested that future warming would accelerate declines in ptarmigan abundance. Although our results showed a clear population level response to variation in climate, we did not detect a density-dependent effect in the ptarmigan population, and we cannot completely explain the inverse relationship between winter temperatures and population growth rates. A process-oriented modeling approach is needed for future studies to elucidate the mechanisms of the effects of climate change on the population dynamics of the white-tailed ptarmigan.
\end{abstract}

KEY WORDS: Breeding phenology $\cdot$ Climate $\cdot$ Climate warming $\cdot$ Population dynamics $\cdot$ Population model $\cdot$ White-tailed ptarmigan

\section{INTRODUCTION}

Predictions of sustained climate warming have caused concerns among conservation biologists and wildlife managers about potential impacts on the distribution and abundance of wildlife species (e.g. Peters \& Lovejoy 1992, Hughes 2000). Several studies have demonstrated the effects of climate on the demography of mammals (e.g. red deer Cervus elaphus; Forchham- mer et al. 1998a) and birds (e.g. pied flycatcher Ficedula hypoleuca ${ }_{i}$ Forchammer \& Post 2000, Winkel \& Hudde 1997). Climate change could influence the dynamics of avian populations (Crick \& Sparks 1999, Saether et al. 2000) by affecting the energy requirements of individuals for thermoregulation and by modifying the availability of food (Forchhammer et al. 1998b, Stevenson \& Bryant 2000). There are clear statistical relationships between climate and selected 
aspects of avian biology, including breeding phenology (Bradley et al. 1999, Dunn \& Winkler 1999), reproductive success (Sheaffer \& Malecki 1996) and population trajectories (Rotella et al. 1996, Sorenson et al. 1998). However, there are few studies that project how anticipated changes in climate might affect population performance and persistence of avian species.

White-tailed ptarmigan (Lagopus leucurus) populations are distributed in naturally fragmented tundra at high elevations in western North America (Braun et al. 1993). It is widely predicted that future warming predominates during winter (National Assessment Synthesis Team 2001, Dickinson 1986). These effects may be particularly important at higher latitudes (Houghton et al. 1995, 1996). Because white-tailed ptarmigan occupy high-elevation alpine habitats in Colorado, increases in mean annual temperature may affect their demography directly. Indirect effects are also possible as a result of compression and fragmentation of their alpine environment as forested habitats move upward in elevation. Here, we exploit a data set on ptarmigan population dynamics to examine the impacts of climate on ptarmigan population dynamics in Rocky Mountain National Park (RMNP). Our objectives were: (1) to identify primary climatic factors potentially affecting the population trajectory of whitetailed ptarmigan populations at Trail Ridge Road, RMNP, from 1975 to 1999; and (2) to project how the population might change under plausible scenarios for climate warming.

\section{MATERIALS AND METHODS}

\subsection{Study site and species}

We studied a population of white-tailed ptarmigan during 1975 to 1999 on a study area of $13.8 \mathrm{~km}^{2}$ adjacent to Trail Ridge Road in RMNP $\left(40^{\circ} 25^{\prime} \mathrm{N}\right.$, $105^{\circ} 45^{\prime}$ W) (Giesen 1977, Giesen et al. 1980, Giesen \& Braun 1993). The study area is above the tree line at an elevation of 3350 to $3572 \mathrm{~m}$. Vegetation on the study site is principally alpine tundra (Braun 1969, Braun \& Rogers 1971); main plant communities include stands of cushion plants such as Dryas octopetala and Silene acaulis, grasses and sedges such as Kobresia myosuroidess, willow-sedge-grass wet meadow, and Krummholz scrub (Braun 1969, Braun et al. 1991). Climate in the study area is continental, with frequent extremes in wind velocity and temperature (Braun 1984). Annual average temperature is about $-3^{\circ} \mathrm{C}$. Precipitation from late September to June is usually in the form of snow and sleet (particularly in early spring), while intense afternoon thundershowers are common during the summer months.

\subsection{Ptarmigan monitoring methods}

We located territories of pairs and single birds using playbacks of male territorial calls (Braun et al. 1973). Territories were searched several times during each breeding season. All birds encountered were captured and banded with unique combinations of aluminum and colored bands, which allowed the birds to be identified in subsequent years without recapturing them. We captured $>90 \%$ of the breeding population each year. It consisted of adults ( $>1 \mathrm{yr}$ old) and yearlings $(<1 \mathrm{yr}$ old). Plumage characteristics were used to distinguish between yearlings and adults (Braun \& Rogers 1971). Hatch dates were estimated by calculating ages of chicks primary based on molt and growth and backdating to time of hatch (Giesen \& Braun 1979).

\subsection{Climate data}

Climate data were obtained from the Niwot Ridge Weather Station, Niwot Ridge Long-Term Ecological Research (LTER) Site, located about $40 \mathrm{~km}$ south of our study site in the same elevation range where ptarmigan live. We used 12 climate variables, including the number of days with minimum temperature below $0^{\circ} \mathrm{C}$ in winter and summer, mean winter and summer monthly minimum temperatures, mean winter and summer monthly maximum temperatures, winter and summer minimum temperatures, winter and summer maximum temperatures, mean winter and summer monthly temperatures, and mean winter and summer monthly precipitation. Summer months were from April to September, and winter months were from October to March of the following year.

\subsection{Modeling approach}

One approach to explore relationships between climatic factors and vertebrate populations is to fit a population model to time series data on population sizes. For example, climatic or environmental covariates can be fit to explain residual variation around a deterministic population model (Forchhammer et al. 1998a). We portrayed the dynamics of the ptarmigan population using the Ricker (1975) model,

$$
N_{t+1}=N_{t} \exp \left(a_{0}-b N_{t}+\Sigma \beta_{i} W_{i}\right)
$$

where $N_{t+1}$ is the population size in year $t+1, N_{t}$ is the population size in year $t, a_{0}$ is an intercept, $b$ is a slope term representing density effects, and $\beta_{i}$ denotes coefficients representing the effects of climate variables 
$W_{i}, i=1,2, \ldots 12$. Coefficients $a_{0}, b$, and $\beta_{i}$ are unknown parameters to be estimated by regressing the differences of natural logarithms of $N_{t+1}$ and $N_{t}$ on $N_{t}$ and $W_{i}$ using PROC MIXED (SAS 1990).

Braun et al. (1991) suggested that the expansion of elk Cervus elaphus herd and range in RMNP might affect the ptarmigan population dynamics. Before we fit the Ricker model, we regressed the population growth rates of ptarmigan, expressed as $\ln \left(N_{t+1} / N_{t}\right)$, on the log-transformed population sizes of elk at Estes Park from 1975 to 1999 to determine if the wintering population size of elk was related to the population dynamics of ptarmigan, and to decide if elk population sizes should be included in the model. We did not have direct estimates of elk population sizes on our tundra study site; however, Braun et al. (1991) reported that the elk wintering at Estes Park used the habitat on our study site. We believe that the population counts of elk at Estes Park are relevant indicators of the elk influence on the ptarmigan populations at Trail Ridge Road.

We converted median hatch dates of ptarmigan from 1975 to 1999 to Julian days and performed linear regressions of the differences of median hatch dates minus July 1 versus the average temperatures of May and June. We also conducted a linear regression of average temperatures of May and June on years from 1975 to 1999 to test if the early summer temperatures significantly changed during the period of our study. Linear regressions were carried out with PROC GLM (SAS 1990).

\subsection{Model selection}

We used the corrected Akaike Information Criterion $\left(\mathrm{AIC}_{\mathrm{c}}\right)$ and the Akaike weights $(w)$ to select the best approximating model and to assess model selection uncertainty (Burnham \& Anderson 1998):

$$
\begin{gathered}
\mathrm{AIC}_{\mathrm{c}}=-2 \log [L(\theta)]+2 K[n /(n-K-1)] \\
w=\exp \left(-0.5 \Delta_{i}\right) /\left[\sum_{r}\left(-0.5 \Delta_{r}\right)\right]
\end{gathered}
$$

where $n$ is the sample size, $K$ the number of unknown parameters, $L(\theta)$ the likelihood function, $r=1, \ldots, R, i=$ $1, \ldots, R, \theta$ the vector of unknown parameters, and $\Delta_{r}$ the difference between the ith model and the lowest AIC $_{\mathrm{c}}$ value among $R$ models (Burnham \& Anderson 1998). The best approximating model has the smallest $\mathrm{AIC}_{\mathrm{c}}$ value among all examined models with a forward-like procedure (McCullagh \& Nelder 1989). This model achieves the optimum compromise between accuracy and precision in predictions (Burnham \& Anderson 1998). Akaike weights can be interpreted as the likelihood that a given model is in fact the best model of the given alternatives considered and the data at hand.

\subsection{Development of future climate scenarios and model projections}

We obtained future climate scenarios from data and climate projections developed for the 'U.S. National Assessment: The Potential Consequences of Climate Variability and Change' (www.usgcrp.gov/usgcrp/nacc/ default.htm) by the VEMAP Phase 2 Data Development group at the National Center for Atmospheric Research (VEMAP website: www.cgd.ucar.edu/vemap/ve298. $\mathrm{html}$ ). We used the 2 general circulation model (GCM) scenarios based on Canadian Climate Center (CCC) and the Hadley Centre simulations and baseline data from the grid cell containing RMNP. The grid cell size containing RMNP is large. The difference in the spatial scale might have invited caveats in predictions for climate conditions on the ptarmigan habitats. However, we believe the GCM-model predictions are best suited for climatic conditions on the ptarmigan habitats because of the topology of the grid cell containing RMNP. We calculated average monthly differences between baseline (without greenhouse or aerosol forcing) and simulated climate (with greenhouse and aerosol forcing). These were then used to compute the average decadal changes in winter minimum temperatures. These changes were added to historical data on temperatures to generate a modified 25-yr climate adjusted for the climate change period in a potential future decade. So, no changes in the interannual variability of the baseline historical period was created, just changes in the modal amplitude of the monthly climate for a 25 -yr period used for a base case analysis. This simplification may miss some potential impacts resulting from the interannual variability of future warming in our projections.

We projected ptarmigan population using the best approximating population models driven by the CCC- or Hadley-based scenarios of the weather variables. This projection allowed us to evaluate how the ptarmigan population would have responded if the weather conditions in the past $25 \mathrm{yr}$ had resembled what the CCC or Hadley models predict for the decade of 2021 to 2030.

\section{RESULTS}

The elk population size at Estes Park was not related to the population growth rates of ptarmigan at Trail Ridge Road $(p=0.23)$. Consequently, we dropped the elk population size from the model of ptarmigan population growth rate. We identified 3 models of population growth rate of the ptarmigan that had reasonable support in the data. The best model had Akaike weights of 0.41 , and showed a negative relationship of population growth rate and winter minimum temperature $\left(W_{9}\right)$. High winter temperatures depressed the 


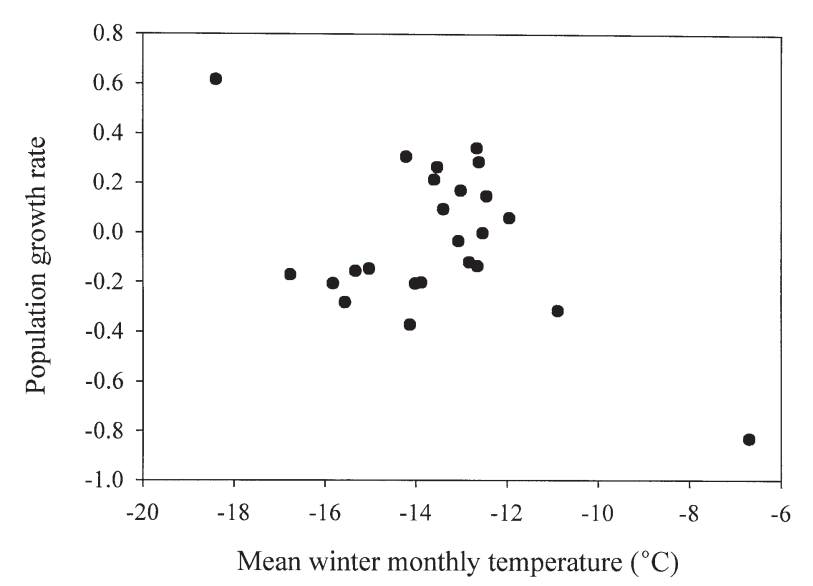

Fig. 1. Relation between ptarmigan Lagopus leucurus population growth rates and mean winter monthly minimum temperatures from 1975 to 1999 at Trail Ridge Road, Rocky Mountain National Park, Colorado, USA

population growth rate. The second and third best approximating models also indicated that high mean winter monthly minimum temperatures $\left(W_{3}\right)$ (Fig. 1) or mean winter maximum temperatures $\left(W_{5}\right)$ could reduce the population growth rate of ptarmigan (Table 1). Generally, the warmer the winter, the lower the population growth rate.

Our selected models did not include the densitydependent term $\left(b N_{t}\right)$ (Table 1). During the forward stepwise modeling selection, the inclusion of the density-dependent term raised the $\mathrm{AIC}_{\mathrm{c}}$ values by about 9 to 10 . In addition, $p$-values of $b$ 's in the fitting were greater than 0.05 ( $\mathrm{p}=0.199,0.209$, and 0.173 , respectively). Therefore, density-dependent effects were not detected in our model fitting.

Median hatch date was negatively related to the average temperatures of May and June (Fig. 2, p = 0.0002). With increasing mean temperatures of May and June, median hatch dates advanced. On average, median hatch dates advanced about $15 \mathrm{~d}$ in the past $25 \mathrm{yr}$ (Fig. 2). A linear regression of the average temperatures of May and June on years indicated a

Table 1. Parameter estimates and Akaike weights for population models of white-tailed ptarmigan Lagopus leucurus at Trail Ridge Road, Rocky Mountain National Park, Colorado, USA. Independent variables: $W_{9}$ (winter min. temp.), $W_{3}$ (mean winter monthly min. temp.), $W_{5}$ (mean winter monthly max. temp.)

\begin{tabular}{|c|c|c|c|}
\hline \multirow{2}{*}{ Model of population size } & \multicolumn{2}{|c|}{ Coefficients } & \multirow{2}{*}{$\begin{array}{l}\text { Akaike } \\
\text { weights }\end{array}$} \\
\hline & $\beta_{0}$ & $\beta_{1}$ & \\
\hline (a) $N_{t+1}=N_{t} \exp \left(\beta_{0}+\beta_{1} W_{9}\right)$ & -0.77 & -0.04 & 0.41 \\
\hline (b) $N_{t+1}=N_{t} \exp \left(\beta_{0}+\beta_{1} W_{3}\right)$ & -0.82 & -0.06 & 0.32 \\
\hline (c) $N_{t+1}=N_{t} \exp \left(\beta_{0}+\beta_{1} W_{5}\right)$ & -0.39 & -0.05 & 0.27 \\
\hline
\end{tabular}

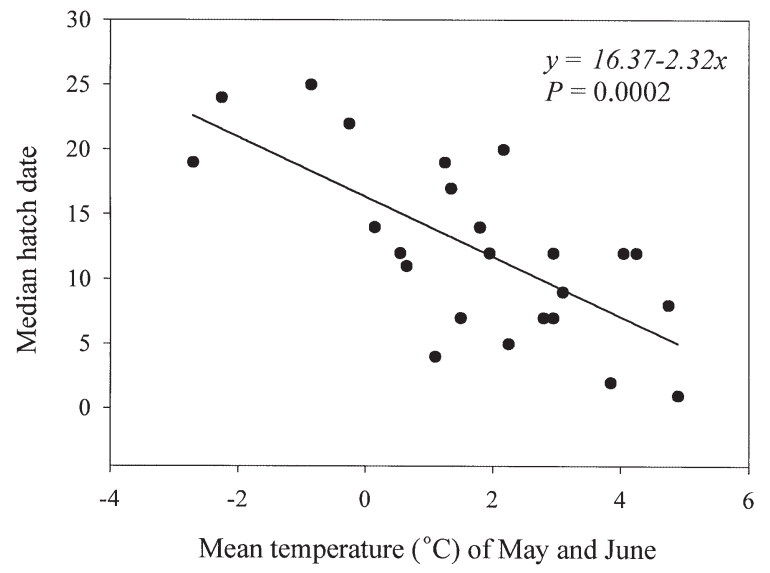

Fig. 2. Linear regression of median hatch dates (July $1=0$ ) on the average temperatures $\left({ }^{\circ} \mathrm{C}\right)$ of May and June from 1975 to 1999

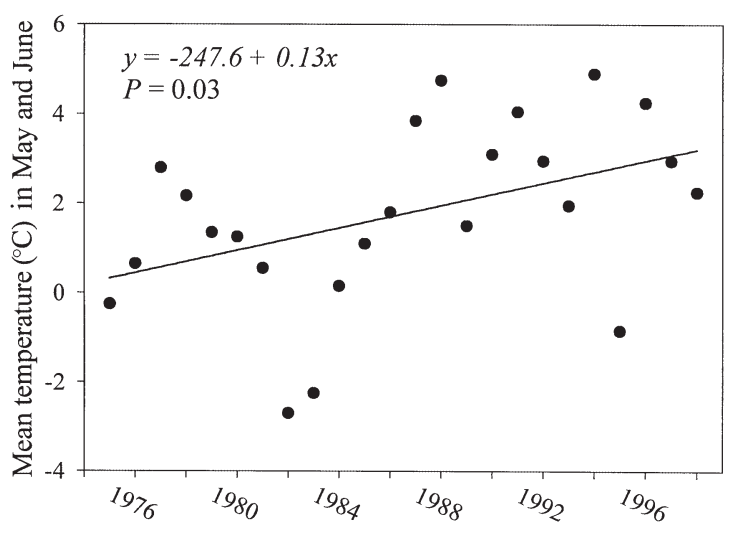

Fig. 3. Linear regression of the average temperatures $\left({ }^{\circ} \mathrm{C}\right)$ of May and June at Trail Ridge Road, Rocky Mountain National Park, Colorado, USA, on years from 1975 to 1999

significant increase in the average temperatures of May and June in the past 2 decades (Fig. 3, p = 0.03). Therefore, the breeding phenology of ptarmigan has been related to increases in spring or early summer temperatures.

The CCC model projects that the minimum winter temperature will increase by about $2.3^{\circ} \mathrm{C}$ on average by 2030 , while the Hadley model projects a minimum winter temperature increase of about $2.6^{\circ} \mathrm{C}$. Scenarios based on these models, coupled with the Ricker population model, suggested that white-tailed ptarmigan at Trail Ridge Road would have declined to 2 or 3 individuals if we had had the weather scenarios predicted by the CCC or Hadley model in the past 2 decades, whereas the observed size and model-predicted size using historic climate data were between 30 and 40 birds (Fig. 4). Therefore, projected temperature increases in RMNP have the 


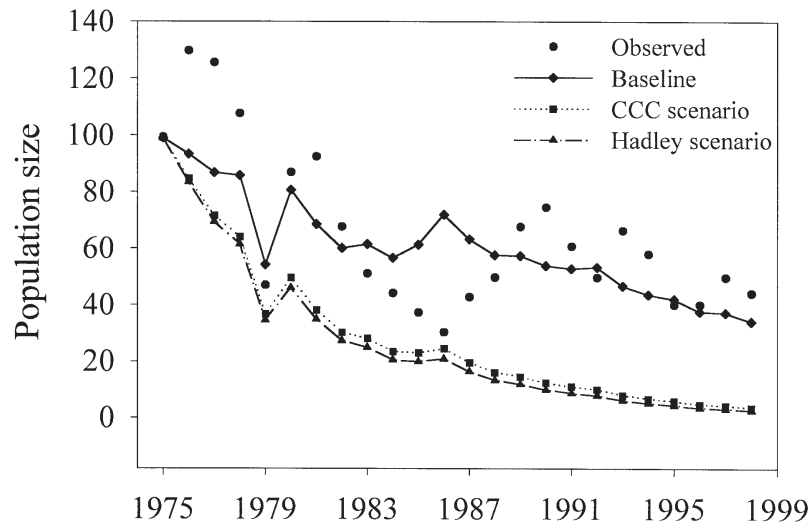

Fig. 4. Model projections of population sizes of white-tailed ptarmigan Lagopus leucurus at Trail Ridge Road, Rocky Mountain National Park, Colorado, USA, based on historic climate data (baseline), Canadian Climate Centre and Hadley model-predicted climate scenarios for the future $30 \mathrm{yr}$

potential to accelerate the decline in ptarmigan abundance and increase the probability of local extinction.

\section{DISCUSSION}

Warm winters retarded the population growth of the ptarmigan. Forchhammer et al. (1998) also reported that warmer winters depressed the population growth rate of common sandpipers Actitis hypoleucos. We could not completely explain this inverse relationship. However, ptarmigan generally select winter habitats with high snow accumulations (Braun \& Schmidt 1971, Braun 1984, Braun et al. 1991). Ptarmigan tunnel in snow to modify their ambient temperature and mitigate extremely cold conditions (Braun \& Schmidt 1971, May 1975). The depth of night roosts ranges from 90 to $270 \mathrm{~mm}$ (Braun \& Schmidt 1971). Warm winters could reduce snow accumulation in the winter habitats and thus limit the population growth of ptarmigan. Additionally, warm, clear and calm conditions in the winter seemed to inhibit activity, and in turn, might impede ptarmigan foraging activity, which is important to the fat level at the beginning of breeding seasons (Braun \& Schmidt 1971).

Evidence suggests climatic warming in the past 2 decades (Fig. 3). Meanwhile, the study ptarmigan population has declined (Fig. 4). Our models projected substantial decline of the ptarmigan population at RMNP using the CCC and Hadley model-based scenarios of future warming (Fig. 4). It is possible that warm climates or winters may cause extinction of white-tailed ptarmigan at Trail Ridge Road. Whitetailed ptarmigan are currently distributed in naturally fragmented alpine habitats (Braun 1984). We expect further fragmentation of white-tailed ptarmigan habitat when the temperature increases and the tree line rises or tundra disappears (N.T.H. et al. unpubl.). This further habitat fragmentation could cause problems for winter migration (Hoffman \& Braun 1975, Giesen \& Braun 1992), as well as reduce dispersal and gene exchanges of ptarmigan among patch habitats and further limit the viability of ptarmigan at RMNP (Giesen \& Braun 1993, Martin et al. 2000).

Median hatch dates of white-tailed ptarmigan at RMNP have significantly advanced in the past 2 decades. This early breeding was related to increasing of May and June temperatures (Fig. 2). In the UK, 27 bird species responded to increasing spring temperatures with earlier egg-laying during 1940 to 1991 (Crick \& Sparks 1999). More recent data from 1971 to 1997 indicate that great tits Parus major have a significant trend towards earlier breeding, whereas they did not show a significant trend of earlier breeding during 1944 to 1970 (McCleery \& Perrins 1998). McCleery \& Perrins (1998) related the recent earlier breeding of great tits to the recent upward trend of spring temperatures from 1971 to 1997 . Similarly, great tits, blue tits P. caeruleus, and pied flycatchers Ficedula hypoleuca in northern Germany had a negative relationship between egg-laying dates and warm winters (Forchhammer \& Post 2000). Early breeding enables birds to produce the most surviving offspring, and consequently, affects population dynamics (Perrins 1970, McCleery \& Perrins 1998). Stevenson \& Bryant (2000) linked the climate-induced changes of the breeding phenology of great tits to the energetic constraints. The increasing spring temperatures may also result in earlier growing seasons and enhance forage availability for birds in Europe (Forchhammer et al. 1998b). The improvement in food availability and fledging survival may have contributed to the increase of population growth (Forchhammer et al. 1998b, McCleery \& Perrins 1998). However, our studies showed that early breeding of ptarmigan did not increase the population growth rates (Figs. $2 \& 4$ ).

The relationships between climate variables and population dynamics of avian species are complex in terms of effects of warming winters on the ptarmigan population. Yalden \& Pearce-Higgins (1997) have demonstrated a positive relationship between the population growth rate of golden plovers Pluvialis apricaria and winter temperatures. However, Forchhammer et al. (1998b) reported that population growth of common sandpipers was depressed by warming winters. Our study suggested that either mean winter monthly minimum temperature, mean winter monthly maximum temperature, or winter minimum temperature was negatively related to the population growth 
rate of ptarmigan. These differences among avian species suggest that avian species have complex life histories to adapt to different climate regimes and changes (Pounds et al. 1999).

Density-dependent effects on population growth rates of white-tailed ptarmigan were not found in our study. The ptarmigan population size has declined to about $1 / 3$ of its peak size (Fig. 4). It is possible that some unidentified factors kept the ptarmigan population below the threshold size above which density-dependent effects are manifested. Our results show a clear population level response to variation in climate. However, in a preliminary analysis, we failed to detect consistent effects of climate on stage-specific and sex-specific survival rates, female reproduction, and recruitment of the ptarmigan. The response is composed of complex effects on demographic parameters. For instance, warmer winters enhanced the survival rates in female and depressed survival rates in male (authors' unpubl. data). In part, sex-specific (female biased) dispersal of white-tailed ptarmigan might have made it more difficult to estimate annual sex-specific and stage-specific survival rates and recruits at RMNP. Moreover, the Niwot Ridge Weather Station is about 40 $\mathrm{km}$ from our study site. The climate data from the Niwot Ridge may not adequately reflect the microclimatic changes on the ptarmigan habitat at RMNP. It is possible that the decline of the ptarmigan population might not be a direct effect of warming at RMNP. Our empirically derived models cannot reveal the mechanism of climate effects on the ptarmigan populations. We need a process-oriented modeling approach to elucidate the mechanisms of population-level responses to climate change.

Acknowledgements. This study was supported by a STAR grant from the United States Environmental Protection Agency (Agreement Number R 827449-01-0). Funding for the ptarmigan studies was provided by the Colorado Division of Wildlife and Colorado Federal Aid to Wildlife Restoration Project W-37-R, W-152-R, and W-167-R. Anonymous reviewers made helpful comments on the manuscript. We are grateful to the Niwot Ridge Long-Term Ecological Research Site for providing long-term climate data.

\section{LITERATURE CITED}

Bradley NL, Leopold AC, Ross J, Huffaker W (1999) Phenological changes reflect climate change in Wisconsin. Proc Natl Acad Sci USA 96:9701-9704

Braun CE (1969) Population dynamics, habitat, and movement of white-tailed ptarmigan in Colorado. PhD thesis, Colorado State University, Fort Collins

Braun CE (1984) Biological investigations of white-tailed ptarmigan in Colorado, USA: a review. In: Hudson PJ, Lovel TWI (eds) 3rd Int Grouse Symp. World Pheasant Association, York University, p 131-147
Braun CE, Rogers GE (1971) The white-tailed ptarmigan in Colorado. Colo Div Game, Fish and Parks, Tech Bull 27: $1-80$

Braun CE, Schmidt RK Jr (1971) Effects of snow and wind on wintering populations of white-tailed ptarmigan in Colorado. In: Haugen AO (ed) Proc Snow and Ice Symp. Iowa Cooperative Research Unit, Iowa State University, Ames, p 238-250

Braun CE, Schmidt RK, Rogers GE (1973) Census of Colorado, white-tailed ptarmigan with tape-recorded calls. J Wildl Manage 37:90-93

Braun CE, Stevens DR, Giesen KM, Melcher CP (1991) Elk, white-tailed ptarmigan and willow relationships: a management dilemma in Rocky Mountain National Park. Trans 56th North Am Wildl \& Nat Res Conf, Edmonton, Alberta, p 74-85

Braun CE, Martin K, Robb LA (1993) White-tailed ptarmigan. The birds of North America, No 68. The Academy of Sciences, Philadelphia and The American Ornithologists Union, Washington, DC

Burnham KP, Anderson DR (1998) Model selection and inference: a practical information-theoretic approach. Springer-Verlag, New York

Crick HQ, Sparks TH (1999) Climate change related to egglaying trends. Nature 399:423-424

Dickinson R (1986) The climate system and modeling of future time. In: Bolin B, Doos B, Jager J, Warrick RA (eds) The greenhouse effects, climate change, and ecosystems. John Wiley, Chichester, p 207-270

Dunn PO, Winkler DW (1999) Climate change has affected the breeding date of tree swallows throughout North America. Proc R Soc Lond Ser B 266:2487-2490

Forchhammer MC, Post E (2000) Climatic signatures in ecology. Trends Ecol Evol 15:286-287

Forchhammer MC, Stenseth NC, Post E, Langvatn R (1998a) Population dynamics of Norwegian red deer: densitydependence and climatic variation. Proc R Soc Lond Ser B 265:341-350

Forchhammer MC, Post E, Stenseth NC (1998b) Breeding phenology and climate. Nature 391:29-30

Giesen KM (1977) Mortality and dispersal of juvenile whitetailed ptarmigan. MS thesis, Colorado State University, Fort Collins

Giesen KM, Braun CE (1979) A technique for age determination and juvenile white-tailed ptarmigan. J Wildl Manage 43(2):508-511

Giesen KM, Braun CE (1992) Winter home range and habitat characteristics of white-tailed ptarmigan in Colorado. Wilson Bull 104(2):263-272

Giesen KM, Braun CE (1993) Natal dispersal and recruitment of juvenile white-tailed ptarmigan in Colorado. J Wildl Manage 57(1):72-77

Giesen KM, Braun CE, May TA (1980) Reproduction and nestsite selection by white-tailed ptarmigan in Colorado. Wilson Bull 92:188-199

Hoffman RW, Braun CE (1975) Migration of a wintering population white-tailed ptarmigan in Colorado. J Wildl Manage 39(3):484-490

Houghton JT, Meira Filho LG, Bruce J, Lee H, Callander BA, Haites E, Harris N, Maskell K (1995) Climate change 1994: radiative forcing of climate change, and an evaluation of the IPCC IS92 emission scenarios. Reports of Working Groups I and III of the Intergovernmental Panel on Climate Change. Cambridge University Press, Cambridge

Houghton JT, Meira Filho LG, Callander BA, Harris N, Kattenberg A, Maskell K (1996) Climate Change 1995: the science of climate change. Contribution of Working 
Group I to the Second Assessment Report of the Intergovernmental Panel on Climate Change. Cambridge University Press, Cambridge

Hughes L (2000) Biological consequences of global warming: is the signal already apparent? Trends Ecol Evol 15:56-61

Martin K, Stacey PB, Braun CE (2000) Recruitment, dispersal, and demographic rescue in spatially-structured whitetailed ptarmigan populations. Condor 102:503-516

May TA (1975) Physiological ecology of white-tailed ptarmigan in Colorado. PhD thesis, University of Colorado, Boulder

McCleery RH, Perrins CM (1998) Temperature and egglaying trends. Nature 391:30-31

McCullagh P, Nelder FJA (1989) Generalized linear models. Chapman \& Hall, London

National Assessment Synthesis Team (2001) Climate change impacts on the United States: the potential consequences of climate variability and change. Report for the US Global Change Research Program. Cambridge University Press, Cambridge

Perrins CM (1970) Timing of birds' breeding seasons. Ibis 112: 242-255

Peters RL, Lovejoy TE (1992) Global warming and biological diversity. Yale University Press, New Haven, CT

Pounds JA, Fogden MPL, Campbell JH (1999) Biological response to climate change on a tropical mountain. Nature 398:611-614

Editorial responsibility: Andrew Comrie,

Tucson, Arizona, USA
Ricker WE (1975) Computation and interpretation of biological statistics of fish populations. Fish Res Board Can Bull 191, Ottawa

Rotella JJ, Ratti JT, Reese KP, Taper ML, Dennis B (1996) Long-term population analysis of gray partridge in eastern Washington. J Wildl Manage 60:817-825

Saether BE, Tufto J, Engen S, Jerstad K, Rostad OW, Skatan JE (2000) Population dynamical consequences of climate change for a small temperate songbird. Science 287: 854-856

SAS (1990) SAS/STAT user's guide. SAS Institute, Cary, NC

Sheaffer SE, Malecki R (1996) Predicting breeding success of Atlantic population Canada geese from meteorological variables. J Wildl Manage 60:882-890

Sorenson LG, Goldberg R, Root TL, Anderson MG (1998) Potential effects of global warming on waterfowl populations breeding in the northern Great Plains. Clim Change 40:343-369

Stevenson IR, Bryant DM (2000) Climate change and constraints on breeding. Nature 406:366-367

Winkel W, Hudde H (1997) Long-term trend in reproductive traits of tits (Parus major, $P$. caeruleus) and pied flycatchers (Ficedula hypoleuca). J Avian Biol 28:187-190

Yalden DW, Pearce-Higgins (1997) Density-dependence and winter weather as factors affecting the size of population of golden plovers (Pluvialis apricaria). Bird Study 44: $227-234$

Submitted: September 4, 2001; Accepted: September 3, 2002 Proofs received from author(s): December 12, 2002 